\title{
PARAPLEGIA AS A SEQUELA TO DORSAL DISC PROLAPSE
}

By Arthur F. Terry, M.D., Terrence McSweeney, F.R.C.S., M.Ch., M.Ch.Orth. and H. W. F. Jones, M.B., F.R.C.P., D.P.M., D.A.

Spinal Injuries Unit, Robert fones $\mathcal{E}$ Agnes Hunt Orthopaedic Hospital, Oswestry, Shropshire, U.K.

Abstract. A retrospective study of seven patients referred to a spinal injury unit following surgery for thoracic disc prolapse is presented. Early diagnosis and increased awareness of the condition followed by lateral rhachotomy or anterolateral decompression is essential if the former dismal prognosis is to be improved.

Key words: Thoracic disc prolapse; Laminectomy; Paraplegia; Antero-lateral decompression.

SEVERE neurological impairment as a result of thoracic intervertebral disc herniation is fortunately rare. Key in $\mathrm{I} 838$ is reported to have described cord injury secondary to thoracic intervertebral disc protrusion in an autopsy specimen (Carson, Gumpert and Jefferson, I97I). Several authors since that time have documented cases of cord injury resulting from thoracic disc prolapse (Middleton and Teacher, I9I I; Mixter and Barr, I934; Hawk, I936; Haley and Perry, I950; Logue, I952; Love and Schorn, 1965).

Surgical treatment of this disorder has acquired a sinister reputation due to a high incidence of neurological deterioration post operatively. The reasons for this are presumably due to delay in diagnosis and surgery, technical problems in an area of anatomical disadvantage and the midline location of many of these disc protrusions. In addition, these protrusions are often calcified, adherent to the dura, and occasionally erode through the dura (Fisher, 1965). Aside from direct cord compression, all of the above factors further jeopardise the tenuous blood supply to the cord in this region.

This paper reviews our experience in the Spinal Injuries Unit at Oswestry with seven patients with paraplegia following laminectomy for thoracic disc prolapse. The review further emphasises the hazards associated with surgical treatment of this disorder.

\section{Clinical Data}

Since 1970, seven patients have been referred to us with paraplegia following thoracic disc prolapse. There are six males and one female. Ages ranged from 35 to 65 with a median of 49 years. The most common level of disc protrusion occurred at D8-9 (three cases). All but one patient have been followed for over I year. Five patients presented with symptoms ranging from I 8 months to 4 years. Two patients presented with a relatively acute clinical course associated with rapid progression (Cases I and 6). Only two patients had a history of trauma and in both it was relatively minor, suggesting the possibility of a pre-existing lesion. Case 5 presented with an 18 -month history of backache and difficulty in walking following a minor fall. The other patient, Case 6 , noted the sudden onset of back pain and progressive weakness after stooping to lift an object. He was found to have a complete cord lesion two weeks after the onset of his symptoms. 


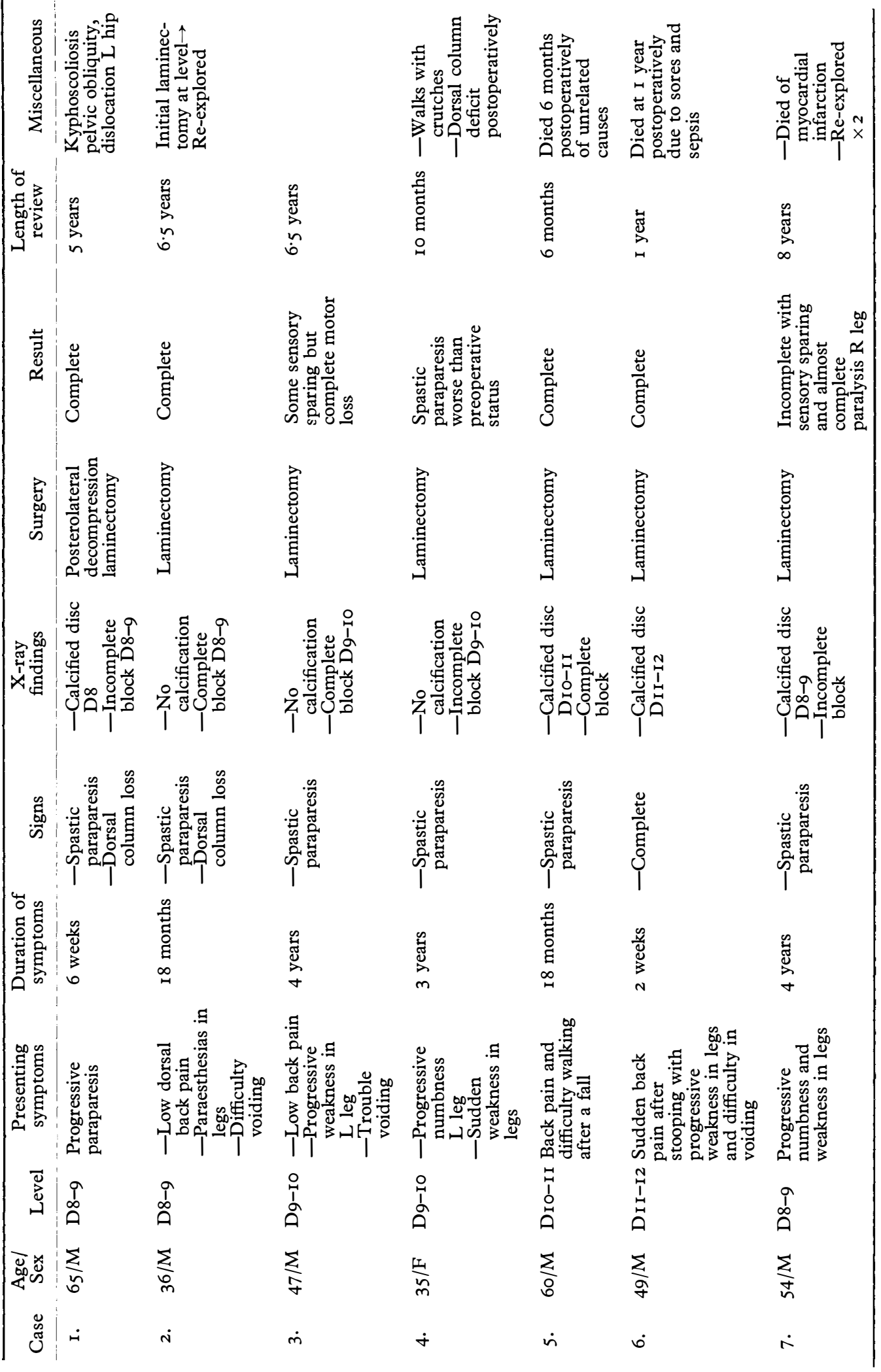


Initial symptoms were sensory in all patients. They included back pain in five patients and numbness or paraesthesiae in three. One of these patients had been misdiagnosed as having multiple sclerosis. All patients complained of weakness of the lower extremities at time of diagnosis. Three patients presented with difficulty in voiding. With the exception of Case 6, all of the remaining patients had a spastic paraparesis pre-operatively. Two patients (Case I and 2) had severe dorsal column involvement pre-operatively demonstrated by loss of vibratory sensation and a positive Rhomberg sign.

Radiographically four patients had a calcified thoracic disc at the level of the lesion. Three patients had no calcification. The lesion was demonstrated in all cases by myelography with incomplete blocks in three patients and complete blocks occurring in four. All patients had exploratory laminectomy usually including three levels. Two patients underwent repeated explorations shortly following the initial laminectomy. One of these patients was initially operated upon at the wrong level and required re-exploration. The paralysis became complete after the first procedure and remained complete. The other patient underwent two consecutive re-explorations due to failure to improve after the initial laminectomy. This patient deteriorated after each procedure, nevertheless he was incomplete after the last operation. Disc excision was performed in all cases.

As mentioned above, one patient was complete preoperatively and remained so postoperatively. Three of the six patients who were incomplete preoperatively became complete and remained complete at review. The patients who were incomplete postoperatively demonstrated gradual return of useful motor function in the lower extremities. In spite of improvement the disability remained severe due to spasticity in two patients (Cases 3 and 7) and dorsal column deficits in one (Case 4 ). Case 4 became ambulatory with the use of crutches but all the others required a wheelchair for ambulation.

One patient (Case I) underwent posterolateral decompression in association with laminectomy. In addition to his complete neurological deficit he has developed a kypho-scoliosis, pelvic obliquity and dislocation of the left hip, postoperatively.

\section{Discussion}

The clinical signs and symptoms of thoracic disc protrusion are dependent upon several factors. These include a small spinal canal which makes the cord vulnerable to even small protrusions (Ransohoff et al., I969), the sparse blood supply to the cord in this region (Dommisse, 1974) and the size and consistency of the protrusion and its relation to the cord and nerve roots (Abbott and Retter, 1956).

There appear to be two clinical courses for this disorder. An acute one in which there is a sudden, severe deficit following a short interval of pain or other sensory disturbances. This pattern was shown by two of our patients. The second, or chronic type, is the more common, slow and progressive medullary compression which the remainder of our patients followed. Isolated radicular symptoms in the absence of cord compression is probably rare in the thoracic region due to the short intraspinal course of the nerve roots with little anatomical contact between the root and the annulus (Arseni and Nash, 1960).

These facts help to explain some of the difficulties in making a diagnosis. Unlike lumbar disc syndromes which typically present with radicular signs and symptoms, there are no symptoms or signs that are 'characteristic' of cord compression in the dorsal region and the symptoms in these cases are not materially different from those of neoplasm except for the traumatic cases (Logue, 1952). 
These varying manifestations have been confused with pleurodynia, intercostal neuritis, intra-abdominal disease, neoplasm, arachnoiditis, disseminated sclerosis, oesophagitis and even familial ataxia and polymyalgia rheumatica (Love and Kiefer, I950; Müller, I951; Logue, 1952; Abbott and Retter, 1956; Shaw, 1975; Benson and Byrnes, 1975; Hodges and Barry, 1975).

One patient in this series was initially diagnosed as having disseminated sclerosis until a myelogram, 3 years after the onset of her initial symptoms revealed a block. The other patients, with the exception of the two who developed rapid neurological impairment, all had a long history of pain, paraesthesia, numbness and eventual paraparesis.

Another factor contributing to the delay in diagnosis is the absence of associated trauma in many cases. Only two patients in this series gave any suggestion of trauma and this was very minor. Previous authors have also failed to demonstrate any direct association between dorsal disc protrusions and trauma (Logue, I952; Love and Kiefer, 1950).

Four out of our seven patients had calcification of the discs on plain X-ray. The presence of this finding is suggestive of dorsal disc protrusion, but its presence is not pathognomonic of a herniated disc (Logue, I952; Svien and Karavitis, I954; Arseni and Nash, I960; Taylor, I964). Calcification of the discs is known to occur in children but its significance is uncertain. There are case reports of calcified disc herniation and neurological compromise occurring in childhood (Maccartee, Griffin and Byrd, I972; Peck, I957; Bradford and Garcia, 1969), but more commonly this calcification follows a benign course (Swick, 1975). Calcification of the nucleus in children is usually transitory and may be only an incidental finding. When symptomatic, there may be local pain associated with a low grade fever but spontaneous resolution over a period of weeks or months is the usual course. Histology of these lesions in childhood shows an amorphous calcification which seems to replace the normal gelatinous nucleus with no evidence of inflammation, neovascularisation, or reactive fibrous tissue (Swick, 1975). In adults this calcification presumably results from degenerative changes and necrosis and the incidence increases with age (Taylor, 1964). Changes in the blood supply surrounding the inter-vertebral disc occurs as a normal ageing process and has an influence on the clinical course of these calcifications (Edgren, Karaharjn and Snellman, 1973). It has been suggested that many of these lesions in adults probably resolve during the course of evaluation of vague symptoms leading to misdiagnoses (Fitzgerald, 1976).

Myelography in these patients was effective in delineating the lesion. Since they may mimic intraspinal tumours both clinically and radiographically on the antero-posterior views, it is recommended that lateral and oblique views be used. This can be combined with tomography or computerised tomography in order to make an accurate pre-operative diagnosis (Taylor, I964; Thomson, I966).

Difficulty arises in deciding when to advise surgery. It is difficult to recommend surgery to a patient who demonstrates little in the way of objective neurological signs. On the other hand, if surgery is delayed until the appearance of overt myelopathy, the results are often disappointing and sometimes disastrous. Patients with long tract signs rarely if ever make full recoveries postoperatively (Love and Kiefer, I950; Logue, I952; Arseni and Nash, 1960). It has also been stated that if symptoms other than pain have been present for over one year, the results of surgery are poor (Hawk, 1936). In view of this, the desirability of operating on patients with herniated discs in the presence of marked deficits might be questioned. However, the clinical course is one of progression and the nature of these space occupying lesions is often not known until surgery. 
The surgical approach to these lesions is difficult and in the case of central protrusions, no particular surgical approach holds an advantage (Reeves and Brown, 1968). Although favourable results have been reported following thoracic laminectomy (Abbott and Retter, 1956; Arseni and Nash, 1960; Fisher, 1965; Maccartee, Griffin and Byrd, I972; Love and Schorn, 1965), there still exists an unacceptably high incidence of neurological deterioration associated with this approach (Mixter and Barr, I934; Hawk, I936; Müller, I95I; Logue, I952; Hulme, 1960). All of the patients in this series deteriorated following laminectomy. More satisfactory results have been reported with the posterolateral approach (Capener, I954; Hulme, I960; Chesterman, I964; Carson, Gumpert and Jefferson, I97I; Jefferson, I975).

It is interesting to note that the one patient in our series who underwent this lateral decompression in addition to laminectomy, developed a severe kyphoscoliosis. This was undoubtedly a contributing factor to his deformity. Favourable results have recently been reported using a transthoracic or anterolateral approach, (Chesterman and Bonney, I964; Perot and Munro, 1969; Ransohoff et al., 1969; Simmons and Evans, 1975; Naylor, 1977). This approach appears to be gaining popularity but it is recommended only when one is reasonably certain that the lesion is extra-dural and anterior.

\section{SUMMARY}

The protean manifestations of thoracic disc prolapse make early diagnosis difficult. Great effort should be taken to make an accurate diagnosis preoperatively. There is no advantage in delaying surgery once symptoms have developed and the diagnosis has been established. Because these patients are referred to the Spinal Unit for assessment and rehabilitation, we see a selected group of patients. Laminectomy in this group of patients was associated with neurological deterioration. In view of this, it would seem that an anterolateral or posterolateral approach to these lesions is preferable when surgery is indicated in the presence of severe myelopathy.

The review of patients in this series indicates that patients who have an incomplete neurological lesion postoperatively may improve and regain some useful motor power with time.

\section{RÉSUMÉ}

Ceci est une étude rétrospective, portant sur sept malades paraplégiques après intervention chirurgicale pour hernie discale dorsale. Tous les malades de cette étude ont subi laminectomie et excision discale. Tous ont vu leur état neurologique se détériorer ou rester inchangé après l'opération. Chez quatre de ces malades, on a pu mettre en évidence une calcification discale au niveau de la hernie. La lésion a été mise en évidence par myélographie dans tous les cas.

Les auteurs insistent sur l'importance d'un diagnostic précoce et sur une appréciation plus précise de l'état clinique, si l'on tient à améliorer un premier pronostic sombre. Il peut être dangereux de retarder l'acte chirurgical une fois que des symptômes suggestifs sont apparus et le diagnostic fait. Quoique cette étude ne concerne qu'un groupe de malades du ressort d'un Centre de chirurgie spinale, il semblerait que l'approche antérolatérale ou transthoracique de ces lésions soit préférable quand la chirurgie est indiquée devant une myélopathie sévère.

\section{ZUSAMMENFASSUNG}

Dies ist eine retrospektive Betrachtung von sieben Patienten mit einer Paraplegie nach chirurgischer Versorgung wegen eines thorakalen Bandscheibenvorfalles. Alle Patienten

I $9 / 2-E$ 
dieser Untersuchungsreihe hatten sich einer Laminektomie und Discusexcision unterzogen. Alle Patienten zeigten postoperativ eine neurologische Verschlechterung oder blieben unverändert. Vier dieser Patienten wiesen im Bereich des Prolapses eine Discuscalcifizierung auf. Die Läsion war in allen Fällen myelographisch nachgewiesen worden.

Die Autoren betonen, daß es wichtig ist, eine frühzeitige Diagnose zu stellen und die Erkenntnisse über die herrschenden Bedingungen zu erhöhen, wenn die bisher traurige Prognose verbessert werden soll. Einige Gefahren liegen in der verzögerten Operation, nachdem signifikante Symptome entwickelt und die Diagnose gestellt worden ist. Obwohl dieser Bericht von einem selektierten Krankengut, das in ein 'Spinal Center' überwiesen wurde, handelt, scheint es, daß ein antero-laterales oder transthorakales Vorgehen bei diesen Läsionen vorzuziehen ist, falls eine chirurgische Intervention bei bestehenden schweren Myelopathien indiziert ist.

\section{Acknowledgement}

The authors wish to thank Mr Bernard Williams for his help in reviewing this article.

\section{REFERENCES}

Aвbott, K. H. \& Retter, R. H. (1956). Protrusions of thoracic intervertebral discs. Neurology, 6, I-IO.

ARseni, C. \& NASH, F. (1960). Thoracic intervertebral disc protrusion. F. Neurosurgery I7, 418 .

Benson, M. K. D. \& Byrnes, D. P. (I975). The clinical syndromes and surgical treatment of Thoracic I.V.D. prolapse. F.B.F.S., 57-B, $47 \mathrm{I}$.

BRADFoRd, D. S. \& GaRCIA, Alexander (I969). Neurological complications in Scheuermann's Disease. Case Report and Literature Review: F.B.F.S., 5I-A, 567.

CAPENER, N. (1954). The evolution of lateral rhachotomy. F.B.f.S., 36-B, I73-179.

CARSON, J., Gumpert, J. \& JEFFERSON, A. (I97I). Diagnosis and treatment of thoracic intervertebral disc protrusion. F. Neurol. Neurosurg. Psychiat., 34, 68-77.

Chesterman, P. J. \& Bonney, G. L. W. (Feb. I964). Spastic paraplegia caused by sequestrated thoracic intervertebral disc. Proceedings of the Royal Soc. of Medicine, 57, $87-88$.

Dommisse, G. F. (May 1974). The blood supply of the spinal cord. F.B.f.S., 56-B, 225-235.

EDGREN, W., KaRAHARJN, E. O. \& SNELlman, O. (1973). Intervertebral disc calcification with complete protrusion intraspongially. Acta Orthop. Scand., 44, 663-667.

FisheR, R. G. (I965). Protrusions of thoracic disc, the factor of herniation through the dura mater. $\mathcal{F}$. Neurosurgery, 22, 591 .

Fitzgerald, R. T. D. (1976). Thoracic discs are different. British Medical fournal, I, IOI9.

Haley, J. C. \& Perry, J. H. (I950). Protrusions of intervertebral discs: a study of their distribution, characteristics, and effects on the nervous system. American fournal of Surgery, 80, 394-404.

HAEK, W. A. (I936). Spinal compression caused by ecchondrosis of the intervertebral fibrocartilage; with a review of the recent literature. Brain, 59, 204-224.

Hodges, C. V. \& BARRY, J. M. (1975). Non-urologic flank pain: a diagnostic approach. The Fournal of Urology, 113, 664 .

Hulme, A. (1960). The surgical approach to thoracic intervertebral disc protrusions. F. Neurol. Neurosurg. Psychiat., 23, I33.

JefFERSON, A. (1975). The treatment of thoracic intervertebral disc protrusions. Clin. Neurol. Neurosurg., 78, (I), I-9.

Logue, V. (1952). Thoracic intervertebral disc prolapse with spinal cord compressions. F. Neurol. Neurosurg. Psychiat., 15, 227.

LOVE, J. G. \& KIEFER, E. J. (I950). Root pain and paraplegia due to protrusion of thoracic intervertebral discs. F. Neurosurgery, 7, 62-69.

Love, J. G. \& SCHORN, V. G. (I965). Thoracic-disc protrusions. F.A.M.A., I9, No. 8, 627.

Maccartee, C. C. Jr., Griffin, P. P. \& Byrd, E. B. (1972). Ruptured calcified thoracic disc in a child. F.B.F.S., 54-A, 1272.

MidDleton, G. S. \& TEACHER, J. H. (I9II). Injury of the spinal cord due to rupture of an intervertebral disc during muscular effort. The Glasgow Medical fournal, 76, I-6. 
MiXTER, W. J. \& BARR, J. S. (I934). Rupture of the intervertebral disc with involvement of the spinal canal. N.E.F.M., 211 , $210-215$.

Muller, R. (I95I). Protrusion of thoracic intervertebral discs with compression of the spinal cord. Acta Medica Scandinavica, 139, 99-104.

NAYLOR, A. (I977). Surgery in the treatment of cervical and thoracic disc protrusions. Brit. Med. F., I, 821 .

PeCK, F. C. Jr. (I957). A calcified thoracic intervertebral disc with herniation and spinal cord compression in a child: Case report. F. Neurosurgery, 14, 105-109.

Perot, P. L. \& Munro, D. D. (1969). Transthoracic removal of mid-line thoracic disc protrusions causing spinal cord compression. f. Neurosurg., 3I, 452-458.

RANSOHOFF, J., SPENCER, F., SIEW, F. \& GAGE, L. (I969). Transthoracic removal of thoracic disc: Report of three cases. F. Neurosurgery, 3I, 459-46I.

REEvES, D. L. \& BROWN, H. A. (I968). Thoracic intervertebral disc protrusion with spinal cord compression. Fournal Neurosurgery, 28, 24-28.

Shaw, N. E. (1975). The syndrome of the prolapsed thoracic intervertebral disc: Editorial. F.B.F.S., 57-B, $4 \mathrm{I} 2$.

Simmons, E. H., Evans, D. C. \& Bailey, S. I. (1975). Thoracic disc disease: in Proceedings of A.O.A./F.B.F.S., 57-A, I 173 .

Svien, H. J. \& Karavitis, A. L. (I954). Multiple protrusions of intervertebral discs in the upper thoracic region: Report of a case. Mayo Clinic Proceedings, 29, 375-378.

Swick, H. M. (I975). Calcification of intervertebral discs in childhood. The fournal of Pediatrics, 86, 3, 364-369.

Taylor, T. K. F. (1964). Thoracic disc lesions: in Proceedings of f.B.F.S., 46-B, 788.

Thomson, J. L. G. (I966). Myelography in dorsal disc protrusion. Acta Radiologica Diagnosis, 5, I I 40-I I 46. 